\title{
Phytotoxic Activity of Guapira graciliflora (Nyctaginaceae) on Weeds
}

\author{
Allana Silva Rodrigues \\ Dept. of Biological Science, Regional University of Cariri, Brazil \\ E-mail: allanarodrigues048@gmail.com
}

\begin{abstract}
José Weverton Almeida Bezerra (Corresponding author)
Dept. of Botany, Federal University of Pernambuco, Av. Prof. Moraes Rego s/n, Cidade

Universitária, Recife, PE 50.670-901, Brazil

E-mail: weverton.almeida@urca.br
\end{abstract}

Viviane Bezerra da Silva

Dept. of Biological Science, Regional University of Cariri, Brazil

E-mail: viviane123silvab@gmail.com

Adrielle Rodrigues Costa

Dept. of Biological Science, Regional University of Cariri, Brazil

E-mail: adrielle.arc@hotmail.com

\section{Felicidade Caroline Rodrigues}

Dept. of Botany, Federal University of Pernambuco, Av. Prof. Moraes Rego s/n, Cidade Universitária, Recife, PE 50.670-901, Brazil

E-mail: rodriguescaroline26@gmail.com

Karina Vieiralves Linhares

Dept. of Biological Science, Regional University of Cariri, Brazil

E-mail: karina_linhares@yahoo.com 
Janete de Souza Bezerra

Dept. of Biological Science, Regional University of Cariri, Brazil

E-mail: janete.bezerra@urca.br

Marcos Aurélio Figueiredo dos Santos

Dept. of Biological Science, Regional University of Cariri, Brazil

E-mail: marcos.figueiredo@urca.br

Maria Arlene Pessoa da Silva

Dept. of Biological Science, Regional University of Cariri, Brazil

E-mail: arlene.pessoa@urca.br

Received: Sep. 1, 2019

doi:10.5296/jas.v8i1.15420
Accepted: Oct. 9, 2019

Published: Dec. 8, 2019

URL: https://doi.org/10.5296/jas.v8i1.15420

\begin{abstract}
The plants produce a variety of compounds that are not directly associated with their growth and are derived from their secondary metabolisms. Such compounds can be used in the formulation of bioherbicides, in the control of weeds. Among the chemical groups that most present allelopathic actions are the phenolic compounds which are present the flavonoids. A species rich in such compounds is Guapira graciliflora, which allows hypothesizing that it may present phytotoxic action. In this way, the objective of this research was to evaluate its phytotoxic action on the germination and growth of Cenchrus echinatus and Calotropis procera. For this purpose, aqueous extracts were prepared from fruits and leaves and applied to seeds of the species mentioned above. Pre and post germinative parameters were measured. Our results show that the extracts can retard the growth of the roots of $C$. echinatus and $C$. procera in a significant way $(p<0.05)$, however it is not able to interfere in the number of germinated seeds or germinated seeds speed. The mechanisms of action of the allelochemicals may be related to inhibition of specific PSII sites or reduction of chlorophyll content. Guapira graciliflora presents allelochemicals in the constitution of its leaves and its fruits that affect the growth of the initial structures of $C$. echinatus and $C$. procera, with potential to be used as bioherbicides in the control of these weeds.
\end{abstract}

Keywords: carrapicho, ciumeira, pau-piranha, bioherbicide, allelochemicals

\title{
1. Introduction
}

Allelopathy, a term created by Hans Molisch in 1937, is defined as any beneficial or harmful 
effect that an organism (vegetables, algae, fungi and microorganisms) exerts in another organism through chemical compounds released into the environment, called allelochemicals (Rice, 2012). These compounds can be produced in various plant organs, from leaves, stems, roots, fruits, seeds to pollen grains, so that they are released through leaching, volatization, root exudation and decomposition of plant remains (Dias et al., 2018; Weston et al., 2012).

Allelopathic substances can be used in the formulation of bioherbicides for weed control, with a great advantage over artificial herbicides, since they are less toxic than agrochemicals and have a rapid degradation with almost null environmental damages (Lopes-Ovejero et al., 2013; Mukerji et al., 2006). In addition, many natural compounds have a mechanism of action similar to that of synthetic herbicides, having the potential to be exploited as bioherbicides, or to be conducted for the discovery of new agrochemicals (Mano, 2006; Tigre et al., 2012).

Amongst the weeds which cause more damage to agriculture are Cenchrus echinatus L. (Poaceae) and Calotropis procera (Aiton) W.T. Aiton (Apocynaceae). The first species is a fast-growing grassland that invades degraded areas and plantations, and in these areas farmers end up injuring themselves due to their spinous diaspores (Ootani et al., 2017; Pacheco \& Marinis, 1984). While C. procera is a species that threatens biodiversity and ecosystem processes, specimens also present several toxic constituents to local fauna and humans (Ahmed \& Dixit, 2005).

The use of synthetic herbicides has advantages over other methods of controlling invasive species, but their use can only be exercised through the selective control for the crop (Scariot et al., 2013). Since the selectivity of a herbicide to a crop defined by efficiency of some molecules to eliminate weeds without decreasing the capacity and quality of the final product (Leandro et al., 2019).

To combat these weeds, become necessary screening of plant species with allelopathic effect for the fractionation, identification and purification of allelochemicals substances that can be used to produce bioherbicides. Therefore, the selection of the species with such potential occurs through field observations, and it is verified in loco if one species interferes in the germination or development of others, or by random approach and finally by means of chemotaxonomic approaches. This is the selection of species of a family or taxonomic genus for which some phytochemical knowledge is available (Albuquerqu \& Hanazaki, 2006; Guirado \& Cuéllar, 2008).

In this way, Nyctaginaceae is a family with more than 350 species, which present a diversity of chemical substances derived from secondary metabolism with allelopathic potentiality (Anaya \& Pelayo-Benavides, 1997; Judd et al., 2009). Among the genera of this taxon, we highlight Guapira Aubl., which presents a total of 60 species, and these present flavonoids, steroids and triterpenoids in their constitution (Severi, 2010), which have herbicidal effects on plant growth (Leandro et al. 2019).

Guapira graciliflora (Mart. ex J. A. Schmidt) Lundell belonging to Nyctaginaceae, popularly known as "maria-mole" and "pau-piranha" is a tree native to Brazil having a chemical composition with steroids, terpenes, flavonoids and saponins, in addition to campesterol, 
stigmasterol, sitosterol and taraxerol, which in an isolated way present allelopathic action (Ma et al., 2011; Severi, 2010). This allows the assumption that it may present allelopathic action on other species (Severi, 2010).

In this sense, due to a growing demand for herbicides of natural origin and because there are gaps evaluating the allelopathic action of several species of Nyctaginaceae, this research aimed to evaluate the allelopathic action of extracts of leaves and fruits of G. graciliflora on the germination and growth of C. echinatus and C. procera.

\section{Material and Methods}

\subsection{Collection and Identification of Botanical Material}

The plant material was collected in a Cerrado area of Chapada do Araripe, Crato-CE, Brazil, in February 2018, $\left(-7^{\circ} 25^{\prime} 08.2^{\prime \prime} \mathrm{S},-39^{\circ} 50^{\prime} 42.5^{\prime \prime} \mathrm{W}\right)$. Fresh leaves and mature fruits of Guapira graciliflora were collected from different individuals, which were packed in 50 L plastic bags in order to maintain humidity. Subsequently, fertile branches were treated according to the usual herbalization techniques, and was identified by Dr. Maria Iracema Bezerra Loiola and then deposited in the Herbarium Caririense Dárdano de Andrade-Lima of the Regional University of Cariri (HCDAL/URCA) under the number of voucher 13.613.

\subsection{Preparation of Plant Extract}

Leaves and fruits of G. graciliflora were used for the preparation of the plant extracts. Two portions ( $30 \mathrm{~g}$ ) of each part of the vegetable (leaf and fruit) were crushed and placed in four beakers. For the hot treatment, distilled water at $100{ }^{\circ} \mathrm{C}$ was added to the botanical material and for the cold treatment, distilled water at $25^{\circ} \mathrm{C}$. The beakers were sealed with film paper, and the material was allowed to stand for $30 \mathrm{~min}$ for the extraction of the compounds. After this period, each content was triturated in a conventional blender for 3 minutes and filtered with the aid of a glass funnel and cotton.

\subsection{Bioassays}

The experiments consisted of four treatments: Hot Extract Leaf (HEL), Cold Extract Leaf (CEL), Hot Extract Fruit (HEF) and Cold Extract Fruit (CEF) with five repetitions each. The control group consisted only of distilled water. For each repetition, 20 seeds of the recipient species were distributed in previously sterilized Petri dishes, containing two sheets of germitest paper moistened with $3 \mathrm{~mL}$ of the different extracts or distilled water (control group). The seeds used were previously sterilized with $5 \%$ hypochlorite for 5 minutes and washed in running water for the same time. Germination tests were carried out for six days in a Biochemical Oxygen Demand (BOD) incubator at $25^{\circ} \mathrm{C}$ and $12 \mathrm{~h}$ photoperiod.

\subsection{Physicochemical Analysis of Extracts}

With the aid of a $\mathrm{pH}$ parameter (Kasvi), the hydrogen of potential $(\mathrm{pH})$ of the extracts were measured and adjusted to a range between 6.0 and 7.5 so that there was no interference on seed germination. The osmotic potential (OP) was also verified with the aid of an osmometer, where the data obtained in mOsm / $\mathrm{kg}$ were converted to osmotic pressure (MPa), according 
to the following equation (Larcher, 2004).

$$
\pi=-\mathrm{W} \times 0.00832 \times \mathrm{Tabs}
$$

Where:

$\boldsymbol{\pi}=$ Osmotic Pressure in MPa;

$\mathbf{W}=$ Osmotic potential in Osm/kg;

Tabs $=$ Absolute temperature, expressed in degrees Kelvin.

\subsection{Analyzed Variables}

\subsubsection{Germination Percentage (GP)}

Seed germination percentage (GP) corresponds to the proportion of the number of seeds that produced seedlings classified as normal and presented their essential structures, such as root system (primary root), shoot (hypocotyl or epicotyl), terminal buds and cotyledons. Percentage values were obtained using the formula proposed by Azevedo Neto (2010):

$\mathrm{GP}=(\mathrm{N} / \mathrm{A}) * 100$

Where:

$\mathbf{N}=$ refers to the total number of germinated seeds at the end of the experiment;

$\mathbf{A}=$ refers to the total number of seeds sown.

\subsubsection{Germination Speed Index (GSI)}

The Germination Speed Index (GSI) is used as an index to evaluate the occupancy velocity of a given plant species in a given environment (FERREIRA; BORGUETTI, 2009). There are reports in the literature that rapid germination is characteristic of species whose evolutionary strategy is to occupy an environment as quickly as possible, whenever appropriate (Bezerra et al., 2018). To determine the GSI the formula of Maguire (1962) was adopted:

$$
G S I=\frac{E^{1}}{N^{1}}+\frac{E^{2}}{N^{2}}+\cdots+\frac{E^{n}}{N^{n}}
$$

Where:

$E^{1}, E^{2}$ and $E^{n}$ is the number of normal emerged seedlings computed at the first, second and last count, respectively; and $\mathrm{N}^{1}, \mathrm{~N}^{2}$ and $\mathrm{N}^{\mathrm{n}}$, is the number of days from sowing to first, second and last count.

\subsubsection{Length of the Stem and Root}

On the last day of the bioassays, five seedlings of each treatment were randomly selected to measure stem and root length. The mediation was performed with the aid of a millimeter ruler. 


\subsection{Statistical Analysis}

For statistical analysis was made ( \pm standard deviation) using the GraphPadPrism 6 with analysis of variance (one way - ANOVA) followed by Tukey test ( $p<0.05$ ). Germination tests were performed in quadruplicate.

\section{Results}

\subsection{Osmolarity and pH Values}

The aqueous extracts of G. graciliflora presented an acid $\mathrm{pH}$, with values lower than 6, of these, the hot extract of the fruits presented the lowest $\mathrm{pH}$ with a value of 4.46. Regarding osmolarity, the highest osmotic pressure was found in the cold extract of the fruits, which presented a value of $-0.163 \mathrm{MPa}$ (Table 1).

Table 1. Physicochemical values of aqueous extracts of G. graciliflora

\begin{tabular}{cccc}
\hline Extract & pH measured & pH adjusted & Osmolarity (MPa) \\
\hline HEL & 5,49 & 6,34 & $-0,093$ \\
CEL & 5,60 & 6,17 & $-0,024$ \\
HEF & 4,46 & 6,11 & $-0,049$ \\
CEF & 4,68 & 6,79 & $-0,163$ \\
\hline
\end{tabular}

HEL: Hot Extract Leaf; CEL: Cold Extract Leaf; HEF: Hot Extract Fruit; CEF: Cold Extract Fruit.

\subsection{Germination Percentage}

The results of the bioassays indicate that the extracts of G. gracilifora do not interfere with the germinability of seeds of $C$. echinatus (Figure 1) or $C$. procera (Figure 2). For $C$. echinatus, the control group had a germinability of $86 \%$, so that the other treatments presented percentages that did not differ statistically from that group. While for C. procera, the control group had $81 \%$ germination, and the other treatments did not prevent seed germination. Thus, G. graciliflora does not present allelochemicals that affect seed germination of recipient species. 


\section{Cenchrus echinatus}

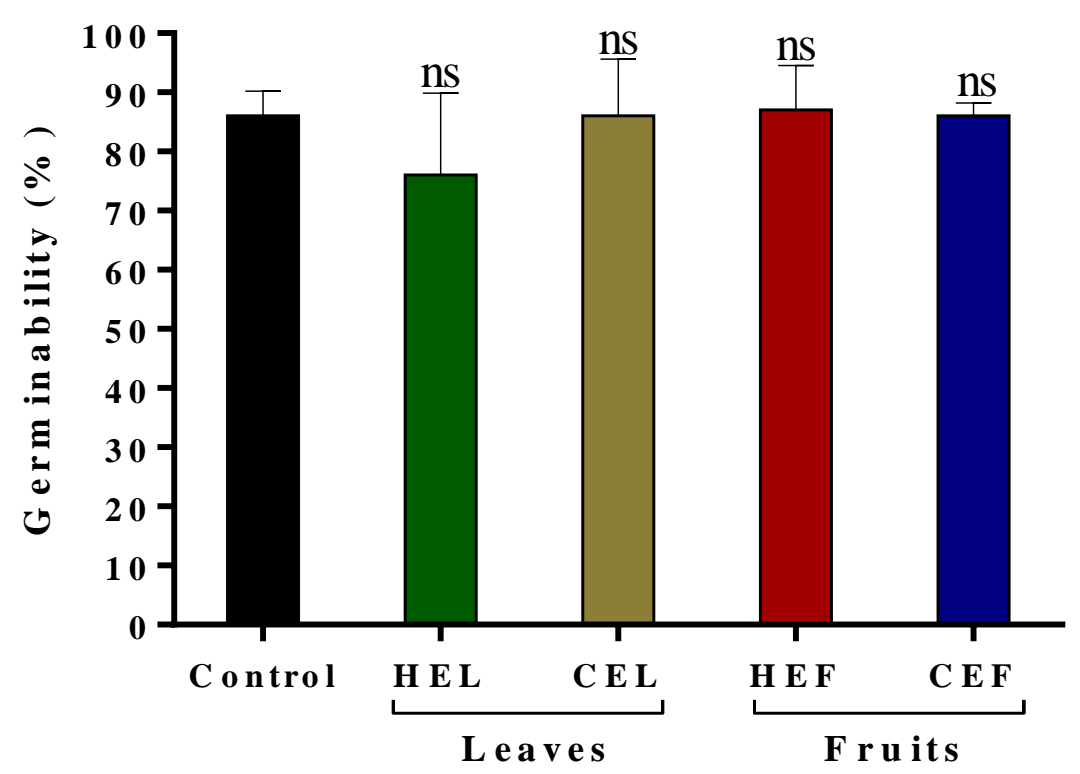

Figure 1. Germination percentage of Cenchrus echinatus seeds submitted to Guapira graciliflora extracts

ns: No statistical significance by the 5\% Tukey test. HEL: Hot Extract Leaf; CEL: Cold Extract Leaf; HEF: Hot Extract Fruit; CEF: Cold Extract Fruit.

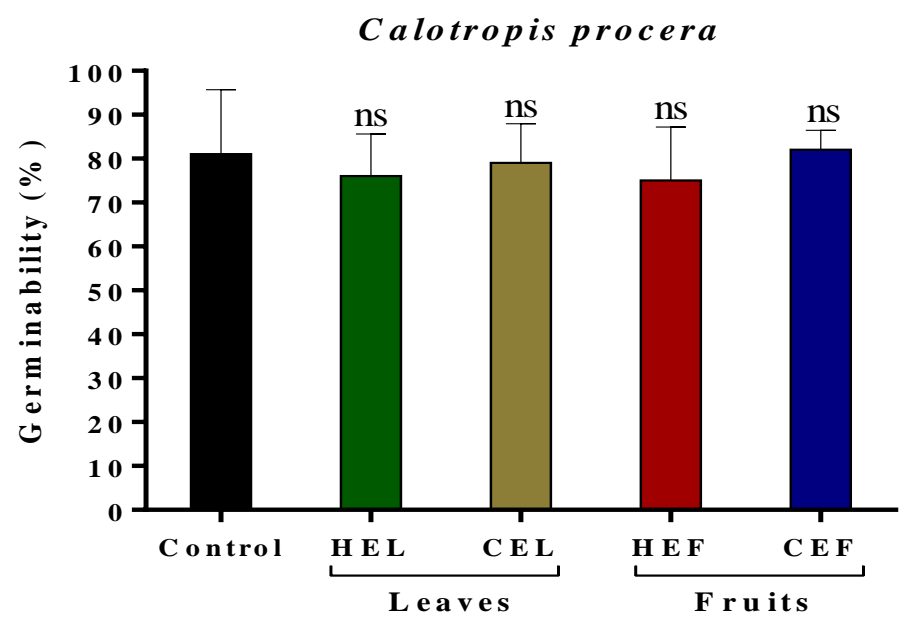

Figure 2. Germination percentage of Calotropis procera seeds submitted to Guapira graciliflora extracts

ns: No statistical significance by the 5\% Tukey test. HEL: Hot Extract Leaf; CEL: Cold Extract Leaf; HEF: Hot Extract Fruit; CEF: Cold Extract Fruit.

\subsection{Germination Speed Index (GSI)}

This germination parameter calculates the speed a seed lot can reach. Thus, the higher value 
obtained in germination, the faster seed germination in a short period of time. The results indicate that the extracts of leaves and fruits of G. graciliflora were not able to change the germination speed of the recipient species under study. Thus, the species does not present allelochemicals capable of interfering with the germination rate of seeds of Cenchrus echinatus and Calotropis procera (Table 3).

Table 3. Germination Speed Index (GSI) of seeds of Cenchrus echinatus e Calotropis procera submitted to the extracts of leaves and fruits of Guapira graciliflora

\begin{tabular}{ccc}
\hline Treatment & C. echinatus & C. procera \\
\hline Control & $9,17 \pm 1,71 \mathrm{a}$ & $4,66 \pm 1,17 \mathrm{a}$ \\
HEL & $7,59 \pm 1,64 \mathrm{a}$ & $4,96 \pm 0,52 \mathrm{a}$ \\
CEL & $8,72 \pm 1,09 \mathrm{a}$ & $4,73 \pm 0,46 \mathrm{a}$ \\
HEF & $8,93 \pm 1,32 \mathrm{a}$ & $5,06 \pm 0,95 \mathrm{a}$ \\
CEF & $8,25 \pm 0,75 \mathrm{a}$ & $5,15 \pm 0,33 \mathrm{a}$ \\
\hline
\end{tabular}

Means followed by the same letter in column do not differ from each other at $5 \%$ probability by Tukey test. HEL: Hot Extract Leaf; CEL: Cold Extract Leaf; HEF: Hot Extract Fruit; CEF: Cold Extract Fruit.

\subsection{Seedling Growth}

Although G. graciliflora extracts did not interfere with the germination of seeds of Cenchrus echinatus and Calotropis procera, allelochemicals of the studied species are able to affect the growth of the initial structures of the receiving species. In the case of $C$. echinatus, as for the growth of the stem, the cold extracts of leaves and fruits were able to cause a negative allelopathic action, since for the CEL there was an average of $7.2 \pm 1.1 \mathrm{~mm}$ of development, and $7.3 \pm 0.6$ for CEF, while for the control group the development of the stem was on average $9.8 \pm 0.6 \mathrm{~mm}$ (Figure 3). 


\section{Cechrus echinatus}

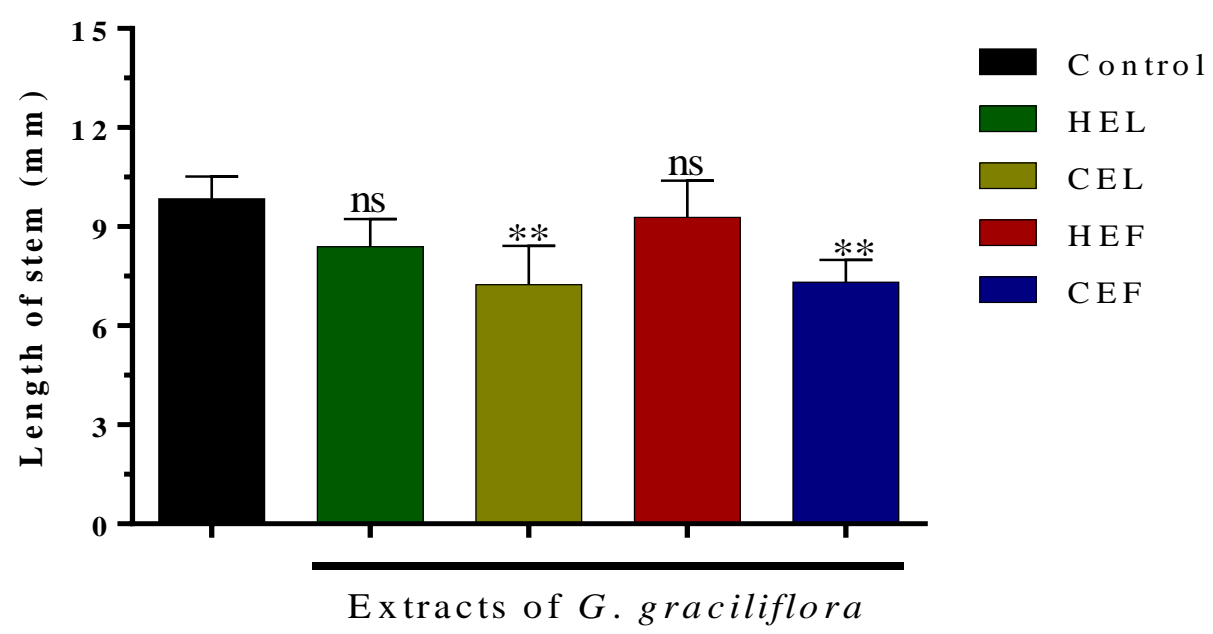

Figure 3. Length of the seedling stem of Cenchrus echinatus under Guapira graciliflora extracts

**: Significance $(p<0,01)$; ns: No statistical significance by Tukey test at 5\%. HEL: Hot Extract Leaf; CEL: Cold Extract Leaf; HEF: Hot Extract Fruit; CEF: Cold Extract Fruit.

Regarding the elongation of C. echinatus root, all extracts of G. graciliflora showed negative allelopathic action. Among the extracts, the most effective in the allelopathic action was the cold extract of the fruits, where the roots submitted to it presented a development of $18.6 \pm$ $4.3 \mathrm{~mm}$ in length, in contrast to the control group that presented a development of $86.8 \pm 3.2$ $\mathrm{mm}$ in length (Figure 4).

Calotropis procera

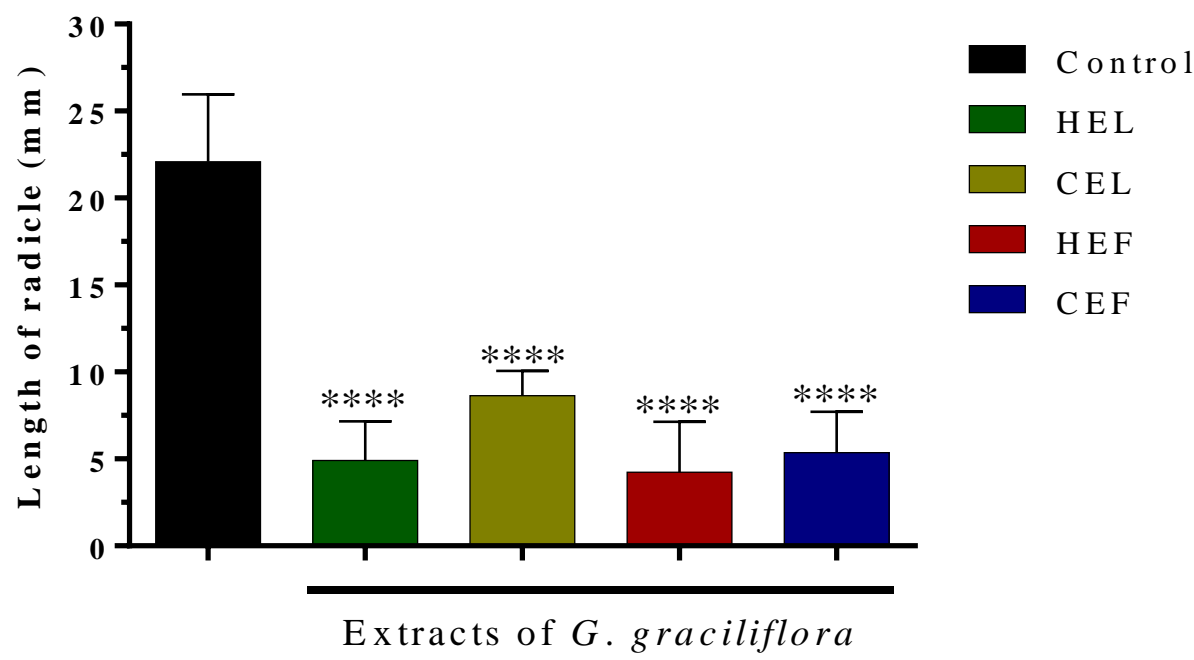

Figure 4. Length of the seedling roots of Cenchrus echinatus under Guapira graciliflora 
extracts

****: Significance $(p<0,0001)$ by Tukey test at 5\%. HEL: Hot Extract Leaf; CEL: Cold Extract Leaf; HEF: Hot Extract Fruit; CEF: Cold Extract Fruit.

As for $C$. procera, the extract of G. graciliflora did not affect seedling stem growing, since the results presented do not differ statistically from the control group $(8 \pm 20.7 \mathrm{~mm})$ as can be seen in Figure 5.

\section{Calotropis procera}

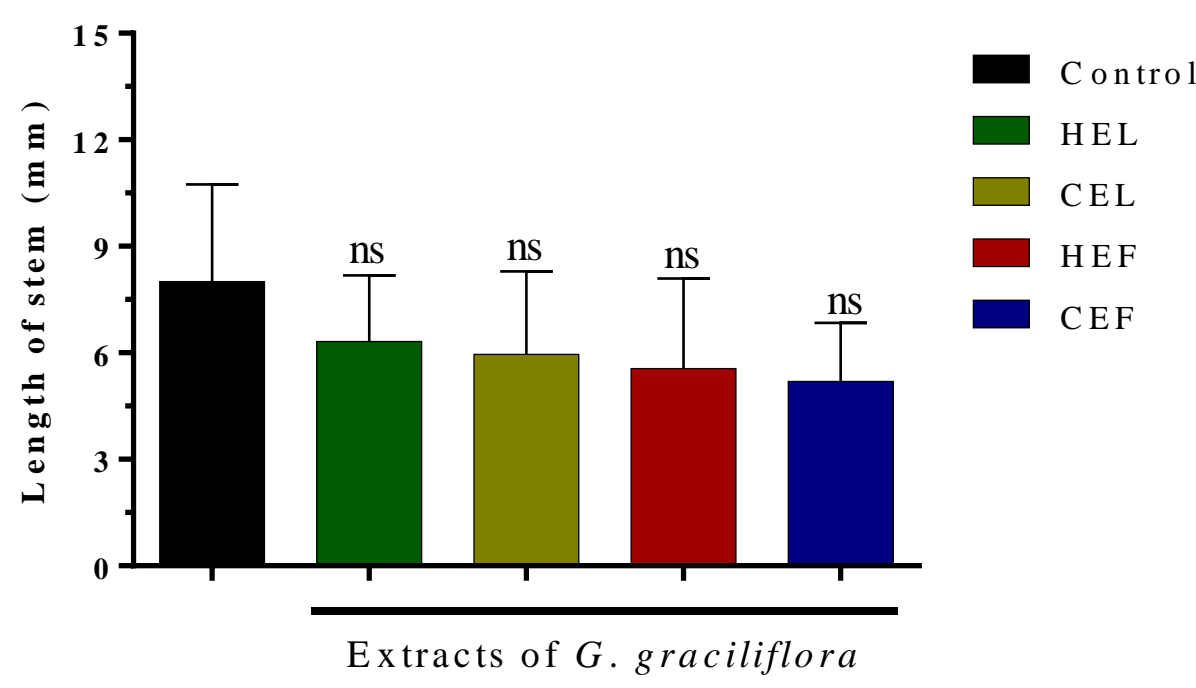

Figure 5. Length of the seedling stem of Calotropis procera under Guapira graciliflora extracts

ns: No statistical significance by Tukey test at 5\%. HEL: Hot Extract Leaf; CEL: Cold Extract Leaf; HEF: Hot Extract Fruit; CEF: Cold Extract Fruit.

However, the extract of the donor species negatively affected the growth of $C$. procera root, because while in the control group the roots grew on average of $22 \pm 3.8 \mathrm{~mm}$, such structures subjected to the various extracts used had a limited growth how can be seen in Figure 6 . 


\section{Calotropis procera}

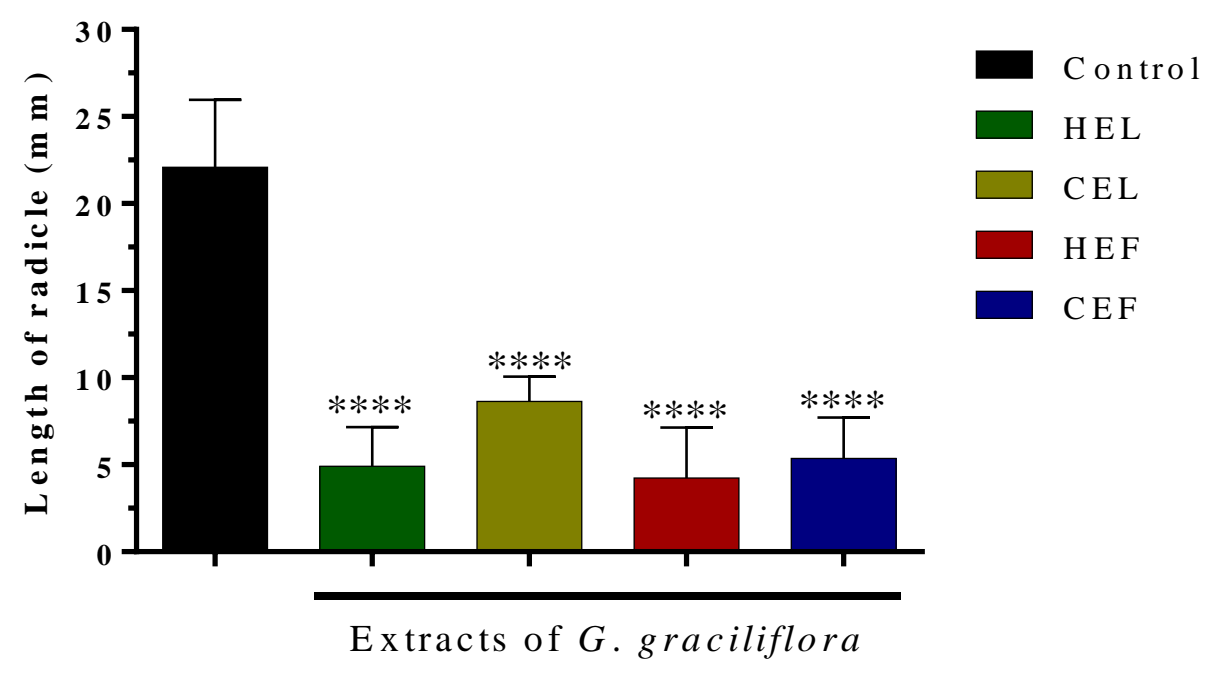

Figure 6. Length of the seedling roots of Calotropis procera under Guapira graciliflora extracts

****: Significance $(p<0,0001)$ by Tukey test at 5\%.. HEL: Hot Extract Leaf; CEL: Cold Extract Leaf; HEF: Hot Extract Fruit; CEF: Cold Extract Fruit.

\section{Discussion}

The osmolarity results obtained in the four treatments present low values and close to zero. The low values represent a lower presence of solute in the extract (sugars, proteins, etc.). In contrast, high values may affect seed germination parameters. Saturated substrates prevent the absorption of water by the seed in order to compromise the metabolic processes of germination (Silva et al., 2019; Bezerra et al., 2019).

Therefore, the analysis of the osmolarity of the extracts is important to be able to show if the extract is preventing the germination of seeds by allelopathic action or only by osmotic pressure. In the case of $C$. echinatus and $C$. procera, these are species sensitive to osmotic pressure. However, in our study, osmolarity values are low, almost close to zero (Klar et al., 2015; Taghvaei et al., 2012; Silva et al., 2019).

Our results indicate that G. graciliflora presents allelochemicals that affect the development of the initial structures of two weeds, $C$. echinatus and $C$. procera. Thus, allelochemicals are not always capable of affecting seed germination, because during this process, seeds need few external resources to promote germination, since their reserves are contained internally. Thus, not all allelochemicals can prevent seed germination (Rice, 2012).

The donor species of this study showed a negative allelopathic action on the growth of stem of $C$. echinatus and, in order for this structure to grow, carbon assimilation through photosynthesis is necessary, and possibly G. graciliflora extracts were able to affect this physiological process. To this end, allelochemicals can act in two ways, or they can inhibit photosystem II (PSII) or decrease chlorophyll content (Huang et al., 2013; Tigre et al., 2012). 
To affect PSII allelochemicals compete for the binding site of the molecule plastoquinone (PQ) on protein D1 of PSII. As for the action on chlorophyll content, allelochemicals may reduce chlorophyll by degrading or inhibiting $\mathrm{Mg}$-porphyrin synthesis. As a result there is a decrease in energy absorption and transfer negatively affecting plant growth and dry weight. (Rice, 2012; Sodaeizadeh et al., 2010).

It is noteworthy that this allelopathic effect on the $C$. echinatus stem is only found in the cold aqueous extracts of $G$ graciliflora. This may be related to the sensitivity of some allelochemicals to high temperatures which leads to their degradation at the time of infusion. Consequently, the concentration of allelopathic agents will be lower in extracts from infusions (Simões et al., 2017).

According to Severi (2010), G. graciliflora presents flavonoids in their constitution, and these compounds act as regulators of ion channels involved in oxidative phosphorylation that can act by closing these channels, thus preventing ions from flowing through the cytoplasmic membrane. When these constituents are in high concentrations in the intracellular environment may hyperpolarize such membranes. It consequently alters the functioning of ATP pumps and therefore affect the growth of receptor seedlings (Martino et al., 2012).

In its chemical constitution G. graciliflora presents campesterol, stigmasterol, sitosterol and taraxerol (Severi, 2010). It can be attributed to allelopathic action observed in the present study such allelopathic compounds since studies with plants such as Euphorbia heterophylla L. indicate the presence of these components in its constitution (Silva et al., 2019).

The observed allelopathic effects on seedling growth may be due to the action of the major components or a synergism of all or some chemical constituents (Bezerra et al., 2018; Simões et al., 2017). Leandro et al. (2019) state that some plants have a variety of allelochemicals in their composition, but in low concentrations, consequently the allelopathic action is nonexistent.

Some herbicides originate from plant species such as commercially sold cineole as Cinmethylin (Shell / USA), hydroxamic acid sold as Benzazin (BASF / Germany) from various grasses and fusaric acid known as Picloran (Dow / USA) (Tigre et al., 2012). In this sense, with allelopathic action verified in weed growth, G. graciliflora may have components that can be used in the formulation of bioherbicides for the control of such weeds.

\section{Conclusion}

Thus, it is evident that the leaves and fruits of Guapira graciliflora have allelochemicals in their constitution that affect the growth of the two weed species under study, so that the species has potential for future use as bioherbicides.

\section{References}

Ahmed, K. M., Rana, A. C., \& Dixit, V. K. (2005). Calotropis Species (Asclepiadaceae) - A Comprehensive Review. Pharmacognosy Magazine, 1(2), 48.

Albuquerque, U. P., \& Hanazaki, N. (2006). As pesquisas etnodirigidas na descoberta de 
novos fármacos de interesse médico e farmacêutico: fragilidades e pespectivas. Revista Brasileira de Farmacognosia, 16, 678-689. https://doi.org/10.1590/S0102-695X2006000500015

Anaya, A. L., \& Pelayo-Benavides, H. R. (1997). Allelopathic potential of Mirabilis jalapa L. (Nyctaginaceae): Effects on germination, growth and cell division of some plants. Allelopathy Journal, 4, 57-68.

Azevedo Neto, E. N. (2010). Potencial alelopático de leucena e de sabiá na germinação, na emergência e no crescimento inicial do sorgo. 2010. 29 p. Monografia (Graduação em Engenharia Florestal) - Universidade Federal de Campina Grande, Patos.

Bezerra, J. W. A., Santos, M. A. F., Meiado, M. V., Linhares, K. V., Boligon, A. A., Leandro, C. S., ... Silva, M. A. P. (2018). Allelopathy of Aromatic Species on the Germination of Cereus jamacaru DC. subsp. jamacaru (Cactaceae). Journal of Agricultural Science, 10(11), 337-348. https://doi.org/10.5539/jas.v10n11p337

Bezerra, J. W. A., Leandro, C. S., Rodrigues, M. D. P., Silva, A. K. F., Silva, D. L., Linhares, K. V., ... Silva, M. A. P. (2019). Allelopathic Activity of Cactus Used in the Foraging in the Brazilian Semi-arid. Journal of Agricultural Science, 11(13), 206-212.

https://doi.org/10.5539/jas.v11n13p206

Dias, A. S., Dias, L. S., \& Pereira, I. P. (2018). Defensive role of allelopathic secondary compounds in plants: a review of data on two independent general hypotheses. Journal of Allelochemical Interactions, 4(1), 9-22.

Ferreira, A. G., \& Borguetti, F. (2004). Germinação do básico ao aplicado. Porto Alegre: ARTMED, p. 323.

Guiradoi, O. A. A., \& Cuéllarii, A. C. (2008). Estrategias en la selección de las plantas medicinales a investigar. Revista Cubana de Plantas Medicinais, 13(3).

Huang, W., Hu, T., Chen, H., Wang, Q., Hu, H., Tu, L., \& Jing, L. (2013). IMPACT of decomposing Cinnamomum septentrionale leaf litter on the growth of Eucalyptus grandis saplings. Plant Physiology and Biochemistry, 70, 411-417.

https://doi.org/10.1016/j.plaphy.2013.06.010

Judd, W. S., Campbell, C. S., Kellogg, E. A., Stevens, P. F., \& Donoghue, M. J. (2009). Sistemática Vegetal: Um Enfoque Filogenético. (3rd ed). Artmed Editora.

Klar, A. E., Pereira, M. R. R., \& Martins, D. (2015). Potenciais hídricos no solo sobre a eficácia de herbicidas em Cenchrus echinatus L. Irriga, 123-138.

https://doi.org/10.15809/irriga.2015v1n1p123

Larcher, W. (2004). Ecofisiologia Vegetal. São Carlos: Rima Artes e Textos, p. 531.

Leandro, C. S., Bezerra, J. W. A., Rodrigues, M. D. P., Silva, A. K. F., da Silva, D. L., dos Santos, M. A. F., \& Bezerra, J. S. (2019). Phenolic Composition and Allelopathy of Libidibia ferrea Mart. ex Tul. in Weeds. Journal of Agricultural Science, 11(2). 
https://doi.org/10.5539/jas.v11n2p109

Lopes Ovejero, R. F., Soares, D. J., Oliveira, W. S., Fonseca, L. B., Berger, G. U., Soteres, J. K., \& Christoffoleti, P. J. (2013). Residual herbicides in weed management for glyphosate-resistant soybean in Brazil. Planta Daninha, 31(4), 947-959.

https://doi.org/10.1590/S0100-83582013000400021

Ma, H., Krock, B., Tillmann, U., Bickmeyer, U., Graeve, M., \& Cembella, A. (2011). Mode of action of membrane-disruptive lytic compounds from the marine dinoflagellate Alexandrium tamarense. Toxicon, 58(3), 247-258.

https://doi.org/10.1016/j.toxicon.2011.06.004

Maguire, J. D. (1962). Speed of germination aid in selection and evaluation for seedling emergence and vigor. Crop Science, 2(2), 176-177.

https://doi.org/10.2135/cropsci1962.0011183X000200020033x

Mano, A. R. O. (2006). Efeito alelopático do extrato aquoso de sementes de cumaru (Amburana cearensis S.) sobre a germinação de sementes, crescimento e crescimento de plântulas de alface, picão-preto e carrapicho. Dissertação (Mestrado em Agronomia) -Universidade Federal do Ceará. Fortaleza, 102 p.

Martino, L., Mencherini, T., Mancini, E., Aquino, R. P., De Almeida, L. F. R., \& De Feo, V. (2012). In vitro phytotoxicity and antioxidant activity of selected flavonoids. International Journal of Molecular Sciences, 13(5), 5406-5419. https://doi.org/10.3390/ijms 13055406

Mukerji, K. G. (2006). Allelochemicals: biological control of plant pathogens and diseases. The Netherlands: Springer.

Ootani, M. A., Dos Reis, M. R., Cangussu, A. S. R., Capone, A., Fidelis, R. R., Oliveira, W., \& Dos Santos, W. F. (2017). Phytotoxic effects of essential oils in controlling weed species Digitaria horizontalis and Cenchrus echinatus. Biocatalysis and Agricultural Biotechnology, 12, 59-65. https://doi.org/10.1016/j.bcab.2017.08.016

Pacheco, R. P. B., \& Marinis, G. (1984). Ciclo de vida, estruturas reprodutivas e dispersão de populações experimentais de capim-carrapicho (Cenchrus echinatus L.) Life cycle, reproductive structures and dispersion of experimental populations of sandbur (Cenchrus ech inatus L.). Planta Daninha, 7(1), 13-21. https://doi.org/10.1590/S0100-83581984000100003

Rice, E. L. (2012). Allelopathy. Academic press.

Scariot, C. A., Vilanova Da Costa, N., Bosquese, E. P., Andrade, D. C., \& Sontag, D. A. (2013). Seletividade e eficiência de herbicidas aplicados em pré-emergência na cultura da mandioca. Pesquisa Agropecuária Tropical, 43(3).

https://doi.org/10.1590/S1983-40632013000300012

Severi, J. A. (2010). Uso sustentável da biodiversidade brasileira: prospecção químico-farmacológica em plantas superiores: Guapira ssp. Tese (Doutorado em Ciências Farmacêuticas) - Universidade Estadual Paulista "Júlio de Mesquita Filho". Faculdade de Ciências Farmacêuticas. Araraquara, 144 p. 
Silva, V. B., Bezerra, J. W. A., Cruz, M. F., Leandro, C. S., Sousa, J. F. O., Santos, M. A. F., ... Silva, M. A. P. (2019). Allelopathy of Dahlstedtia araripensis on Calotropis procera and Zea mays. Journal of Agricultural Science, 11(14), 32-46.

https://doi.org/10.5539/jas.v11n14p32

Simões, C. M. O., Schenkel, E. P., De Mello, J. C. P., Mentz, L. A., \& Petrovick, P. R. (2017). Farmacognosia: do Produto Natural ao Medicamento. Porto Alegre: Artmed, 502 p.

Sodaeizadeh, H., Rafieiolhossaini, M., \& Van Damme, P. (2010). Herbicidal activity of a medicinal plant, Peganum harmala L., and decomposition dynamics of its phytotoxins in the soil. Industrial Crops and Products, 31(2), 385-394.

https://doi.org/10.1016/j.indcrop.2009.12.006

Taghvaei, M., Khaef, N., \& Sadeghi, H. (2012). The effects of salt stress and prime on germination improvement and seedling growth of Calotropis procera L. seeds. Journal of Ecology and Environment, 35(2), 73-78. https://doi.org/10.5141/JEFB.2012.011

Tigre, R. C., Silva, N. H., Santos, M. G., Honda, N. K., Falcão, E. P. S., \& Pereira, E. C. (2012). Allelopathic and bioherbicidal potential of Cladonia verticillaris on the germination and growth of Lactuca sativa. Ecotoxicology and Environmental Safety, 84, 125-132. https://doi.org/10.1016/j.ecoenv.2012.06.026

Weston, L. A., Ryan, P. R., \& Watt, M. (2012). Mechanisms for cellular transport and release of allelochemicals from plant roots into the rhizosphere. Journal of Experimental Botany, 63(9), 3445-3454. https://doi.org/10.1093/jxb/ers054

\section{Copyright Disclaimer}

Copyright for this article is retained by the author(s), with first publication rights granted to the journal.

This is an open-access article distributed under the terms and conditions of the Creative Commons Attribution license (http://creativecommons.org/licenses/by/4.0/). 